\title{
Geochemical Evaluation of Groundwater using Electrical Resistance and Physiochemical Methods: A Case Study of Iba Residential Area, Lagos, Nigeria
}

\author{
B.R. Adegbola ${ }^{1}$, A.O. Majolagbe ${ }^{2, *}$ \\ ${ }^{1}$ Department of Physics, Lagos State University, Ojo, Lagos, Nigeria. \\ ${ }^{2}$ Department of Chemistry, Lagos State University, Ojo, Lagos, Nigeria.
}

\section{A R T I C L E D E T A I L S}

Article history:

Received 28 December 2018

Accepted 26 January 2019

Available online 11 February 2019

Keywords:

Geophysical

Physiochemical

Potable

Aquifer

Schlumberger

\begin{abstract}
A B S T R A C T
Geophysical and physiochemical methods were applied to determine potability of groundwater at Iba area, Ojo, Lagos State, Nigeria. The geophysical methods employed for the survey were Vertical Electrical Sounding and Horizontal Profiling, with the aim of determining the depth of potable groundwater. Ten vertical electrical soundings were conducted using the Schlumberger configuration and three horizontal spread covering the entire area. The VES data were interpreted using (WIN RESIST) which showed that the area is composed of top soil, clay, clayey sand, sandy clay and sand. The horizontal profiling data was subjected to iteration software (DIPPRO) which gave the imaging of the lateral variation in resistivity within the study area. The physiochemical analyses of groundwater samples collected in the study area also conducted following standard procedure. The results of the physicochemical analysis compared with acceptable standards of World Health Organization, showed that the water quality within the study area is wholesome. The geophysical results indicated that real aquifer exist at depth from $20 \mathrm{~m}$. The unconfined aquifer is prone to pollution mostly close to the surface. Potable water is therefore recommended to be sunk via borehole at depth from $30.2 \mathrm{~m}$, with the best at VES 4, 8 and 9 .
\end{abstract}

\section{Introduction}

Water is one of the nature's resources used by human in day to day life such as agriculture, household and industrial use. It has been gifted by nature in bounteous proportion with its quality of transformation through perennial hydrogeological evaporation, condensation, and precipitation. Exploration for groundwater is one of the most valuable natural resources and its effective aid in life on earth requires a number of techniques. Furthermore, high rate of urbanization is also known to have contributed to increased water demand globally [1]. Groundwater is located beneath earth's surface in soil pore spaces and in the fractures of rock formation. It recharges from the ground and eventually flows to the surface naturally. The natural discharge occurs at spring and seeps. The use of geophysics provides the tool for both groundwater resource mapping and for water quality evaluations. Many geophysical techniques have been applied to groundwater with some showing more success than others [2-3]. The methods that have proved particularly effective for groundwater studies including the electrical and electromagnetic. This is because many of the geological formation properties that are critical to hydrogeology such as porosity and permeability of rocks can be correlated with electrical conductivity signatures. Many of these geophysical techniques have been intensively used for groundwater characterization, however, the greatest success has been shown with the electrical method [4]. It is well known that resistivity methods can be successfully employed for groundwater investigations, where good electrical resistivity contrast exists between the water-bearing formation and the underlying rocks [5]. This method is regularly used to solve a wide variety of groundwater problems such as determining the depth, thickness and boundary of an aquifer [6].

Nfor [7] worked on the extent and distribution of groundwater resources in parts of Anambra state, Nigeria using vertical electrical sounding. Their investigation revealed that the state is underlain by four different geologic formations namely; Alluvial Plain Sands, Ogwashi-Asaba Formation, Ameki/Nanka Sands and Imo Shale with depth to water table ranging from 50 to $110 \mathrm{~m}$. Badmus and Olatinsu [8], carried out a study on aquifer characteristics and groundwater recharge pattern in a typical basement complex: Abeokuta, Southwestern Nigeria. The study revealed that Abeokuta has seven major geological formations which are topsoil shale or clay, sandy clay, clayey sand, sandstone, fractured basement and fresh basement. It was also revealed that the weathered and fractured basement constitutes the main aquiferous units in the area. They were able to observe that the reason for borehole failure and poor recharge in the area is attributed to inadequate geophysical investigation.

Sources of pollutants in soil and groundwater environment include disposals of solid wastes, and discharge of effluent from industries [9]. Uncontrolled releases of pollutants will contaminate soil and groundwater, thereby affecting the environment and human health. The increasing vulnerability of soil and groundwater to varying forms and degree of pollution in recent times has become an important environmental issue in the world $[10,11]$.

The use of hydrochemical characterisation employing physicochemical quality parameters; total dissolved solids (TDS), chloride, sulphate and electrical conductively (EC) as well as a wide range of water quality models and indices are gaining popularity in the world of environmental researches. These quality models and indices include sodium percentage (Na \%), sodium adsorption ratio (SAR), residue sodium carbonate (RSC), water quality index (WQI) and permeability index (PI) [12]. Nishanthiny et al., [13] conducted hydro chemical analysis in Sri Lanka in order to evaluate the suitability of the irrigation water quality and confirmed a good percentage of the tested wells have good quality water for irrigation.

Abdulaziz et al., [14] employed both geoelectrical and hydrochemical methods for the investigation of groundwater in coaster plains Saudi Arabia. The results of investigation were integrated to delineate the salt water intrusion zone. Four different types of zones were delineated and concluded that all the zones have high TDS and chloride concentration in major region of the zones. The researchers recommended that drilling of new well should be avoided in the transition zone to prevent further advancement of sea-water.

Therefore, this study was designed to determine the groundwater quality potentials within Iba area, using a combination of electrical resistivity and physiochemical analytical methods, thereby generating data as a base line for relevant agencies in ensuring provision of potable water and sustainable environment. 


\section{Experimental Methods}

\subsection{Study Area}

Lagos state lies approximately between longitudes $2^{\circ} 42^{\prime}$ and $4{ }^{\circ} 42^{\prime} \mathrm{E}$ and latitude $6^{\circ} 22^{\prime}$ and $6^{\circ} 52^{\prime} \mathrm{N}$. The southern boundary of the state lies along the Atlantic coastline as shown in Fig. 1. While it's northern and eastern boundaries are shared with Ogun State. On the western side the boundary is bordered by the republic of Benin. Its size is about 3,577 square kilometer which accommodates over nine million of the national population. It is identified that the geology is made up of sedimentary rock mostly of alluvia deposit, these consist of loose and light grey sand mixed seriously with varying proportion of vegetation matter on the low land, while the reddish and brown loamy soil exist in the upland.

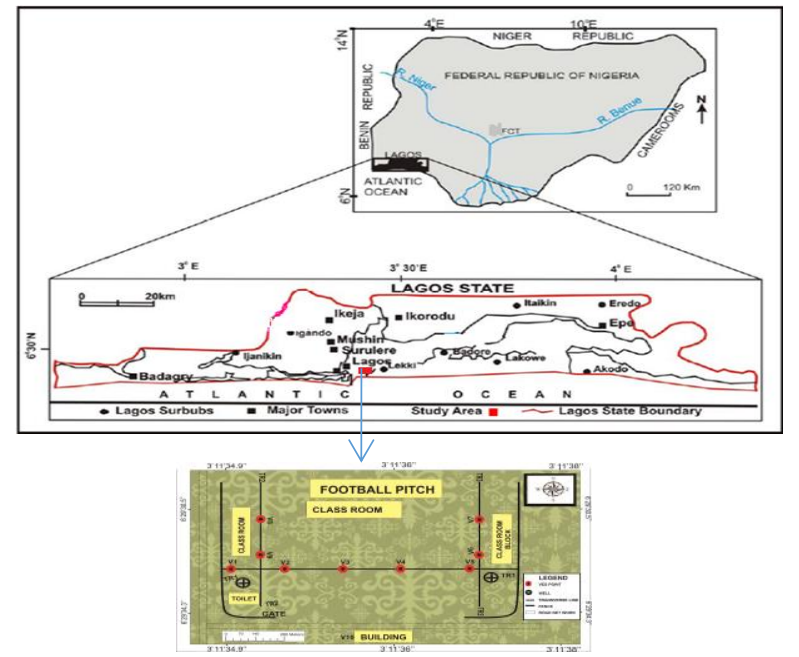

Fig. 1 Map of the sampling location of vertical electric sounding (VES) and profiling positions

The study was carried out in Iba area (Iba nursery/primary school), Ojo local government of Lagos with longitude $3^{\circ} 9^{\prime}$ and 3०38' E and latitude $6^{\circ} 34^{\prime}$ and $6^{\circ} 30^{\prime} \mathrm{N}$. It is a school with population over 500 pupils.

\subsection{Electrical Sounding Measurement}

Vertical electrical sounding (VES) data were collected in 10 stations with maximum current electrode separation of $200 \mathrm{~m}$. Also three (3) horizontal profiling using Wenner array with minimum electrode separation (AB) of $130 \mathrm{~m}$ was carried out (Fig. 1). These methods were adopted because it is considered most appropriate in a sedimentary basin and is simpler and more economical than other geophysics methods [15].

PASI-16GL resistivity meter was used to measure the potential difference $(\Delta V)$ from which resistance $(R)$ is computed and converted into apparent resistivity $\left(\mathrm{P}_{\mathrm{a}}\right)$ at each VES point. The data were interpreted using partial curve matching technique with two-layer Schlumberger master curves and the auxiliary $\mathrm{K}-\mathrm{Q}$ and $\mathrm{A}-\mathrm{H}$ curves. The outputs were model using computer iteration WINRESIST software to obtain the true resistivity and thickness of the various layers. Wenner array was analyzed using computer iteration software (DIPPRO) to process the data acquired through Wenner configuration.

\subsection{Chemical Analysis}

Water samples were collected from two different hand dug wells in the study area bimonthly, for six months consecutively and analysed for various physicochemical parameters using standard procedures. The $\mathrm{pH}$ (pH meter, pHep HANNA HI 98107), electrical conductivity (Mettler Toledo) and temperature (thermometer, $0-100{ }^{\circ} \mathrm{C}$ ) of the water samples were determined in-situ. Total suspended solids (TSS), total dissolved solids (TDS), total solids (TS), chloride, and sulphate, were determined using American Public Health Association methods [16]. Na was analysed using flame photometer and other trace metals by flame atomic absorption spectrophotometer (Buck scientific 210VGP model).

\section{Results and Discussion}

The vertical electric sounding data were analyzed and apparent resistivity curves were drawn, field curves were observed qualitatively to get an idea of the numbers of layers and the resistivity of the layers. It was observed that the dominant types of curves were QHA indicating five layers except in one station which shows HA. The curves show that the https://doi.org/10.30799/jespr.154.19050102 topsoil has both low resistivity and high resistivity since the subsurface is composed of varying superficial earth materials. The second and third layers tend to show similar trend along the profiles with signatures of sand, clay and sandy clay sediments. The forth layers depicted of sand formation with comparatively low resistivity within the study area, these corresponds to confined aquifers.

Interpretation of the data was also done quantitatively using Winresist software. This program calculates and displays the information on the number of layers, resistivity, thickness and depth of each station. Figure 2, shows a graphical interpretation and presentation of the resistivity data and the model parameters of some sounding points in the study area. These resistivity data are shown in Table 1.

It was observed that the confined aquifers thickness varies from $16 \mathrm{~m}$ to $123 \mathrm{~m}$, these were protected by clay materials having variable thickness in the range $6 \mathrm{~m}$ to $14 \mathrm{~m}$. this layer in all the VES stations is adjudged to be a preferred source of potable water for the pupils/people in the study area.
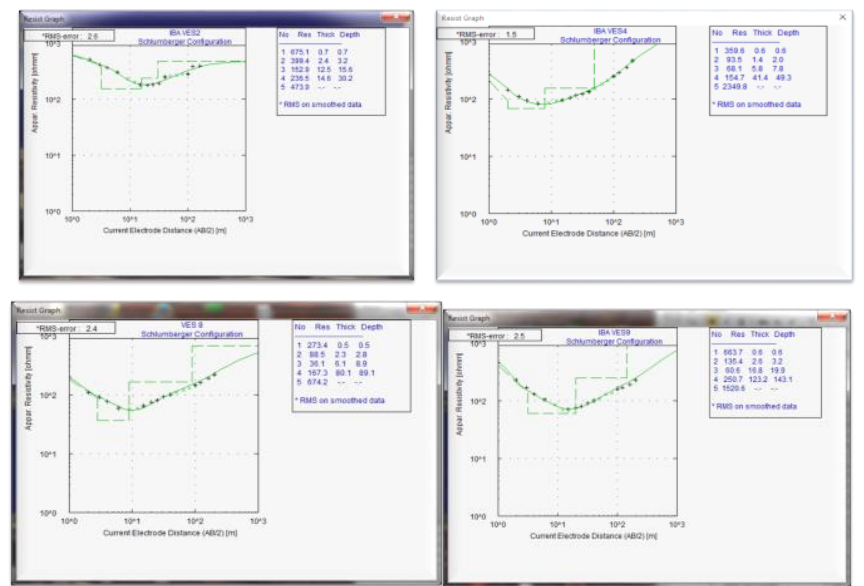

Fig. 2 Graphical presentations of some sounding points with model parameters

The resistivity distribution in two dimensions is shown in Fig. 3, both laterally and vertically. This was done to further diagnose the character of the sediments up to $5 \mathrm{~m}$ depth. The 2D subsurface images obtained from the inversion of the Wenner resistivity data show both the lateral and vertical variations in subsurface resistivity across the different traverses. The 2D images reveal three major subsurface lithology which are (generally in blue colour band with resistivity values less than $100 \Omega \mathrm{m}$ ), sand (generally in green/yellow colour band with resistivity values less than $180 \Omega \mathrm{m}$ ), and clayey sand (generally in tred/brownish colour band with resistivity values ranging from 180 to $408 \Omega \mathrm{m}$ ). A description of the lithology is denoted on the subsurface image obtained across each traverse as presented. This correlated relatively well when compare with the VES results obtained in Table 1.

Table 1 Table of resistivity and thickness of geoelectrical layers

\begin{tabular}{llllll}
\hline Ves no & $\begin{array}{l}\text { Resistivity } \\
\text { values }(\Omega \mathrm{m})\end{array}$ & $\begin{array}{l}\text { Thickness } \\
(\mathrm{m})\end{array}$ & $\begin{array}{l}\text { Depth } \\
(\mathrm{m})\end{array}$ & $\begin{array}{l}\text { Infered } \\
\text { sediment }\end{array}$ & $\begin{array}{l}\text { Curve } \\
\text { types }\end{array}$ \\
\hline VES 1 & 500.0 & 0.6 & 0.6 & Topsoil & QHA \\
& 214.0 & 1.8 & 2.4 & Sandy clay & \\
& 125.0 & 9.9 & 12.3 & Sand & \\
& 6460.0 & - & - & Clayey sand & \\
VES 2 & 675.1 & 0.7 & 0.7 & Topsoil & QHA \\
& 399.4 & 2.4 & 3.2 & Sandy clay & \\
& 152.9 & 12.5 & 15.6 & Sand & \\
& 236.5 & 14.6 & 30.2 & Sandy clay & \\
& 473.9 & - & - & Sandy clay & \\
VES 3 & 431.1 & 0.8 & 0.8 & Topsoil & QH \\
& 80.6 & 5.5 & 6.3 & Sand & \\
& 14.7 & 2.6 & 9.0 & Clay & \\
& 471.7 & - & - & Clayey sand & \\
VES4 & 359.6 & 0.6 & 0.6 & Topsoil & QHA \\
& 93.5 & 1.4 & 2.0 & Sand & \\
& 68.1 & 5.8 & 7.8 & Clay & \\
& 154.7 & 41.4 & 49.3 & Sand & \\
& 2349.8 & - & - & Clayey sand & \\
VES 5 & 181.7 & 0.7 & 0.7 & Topsoil & KQH \\
& 334.9 & 2.6 & 3.2 & Sandy clay & \\
& 84.6 & 6.8 & 10.0 & Sand & \\
& 43.8 & 9.6 & 19.6 & Clay & \\
& 549.0 & - & - & Clayey sand & \\
\hline & & & & &
\end{tabular}




\begin{tabular}{llllll}
\hline VES 6 & 33.7 & 0.4 & 0.4 & Topsoil & KHK \\
& 165.1 & 0.8 & 1.2 & Sand & \\
& 28.2 & 4.4 & 5.6 & Sand & \\
& 466.2 & 19.8 & 25.4 & Clayey sand & \\
& 70.1 & - & - & Clay & \\
VES 7 & 151.2 & 0.6 & 0.6 & Topsoil & HA \\
& 66.4 & 13.3 & 13.9 & Clay & \\
& 358.7 & 73.2 & 87.1 & Sand & \\
& 3590.4 & - & - & Clayey sand & \\
VES 8 & 273.4 & 0.5 & 0.5 & Topsoil & QHA \\
& 88.5 & 2.3 & 2.8 & Sand & \\
& 36.1 & 6.1 & 8.9 & Clay & \\
& 167.3 & 80.1 & 89.1 & Sand & \\
& 674.2 & - & - & Sandy clay & \\
VES 9 & 663.7 & 0.6 & 0.6 & Topsoil & QHA \\
& 135.4 & 2.6 & 3.2 & Sand & \\
& 60.6 & 16.8 & 19.9 & Clay & \\
& 250.7 & 123.2 & 143.1 & Sand & \\
& 1520.6 & - & - & Sandy clay & \\
VES 10 & 161.1 & 0.5 & 0.5 & Topsoil & KHA \\
& 278.4 & 2.6 & 3.2 & Sandy clay & \\
& 70.6 & 13.7 & 16.9 & Clay & \\
& 114.4 & 16.7 & 33.6 & Sand & \\
& 273.8 & - & - & Sandy clay & \\
\hline
\end{tabular}
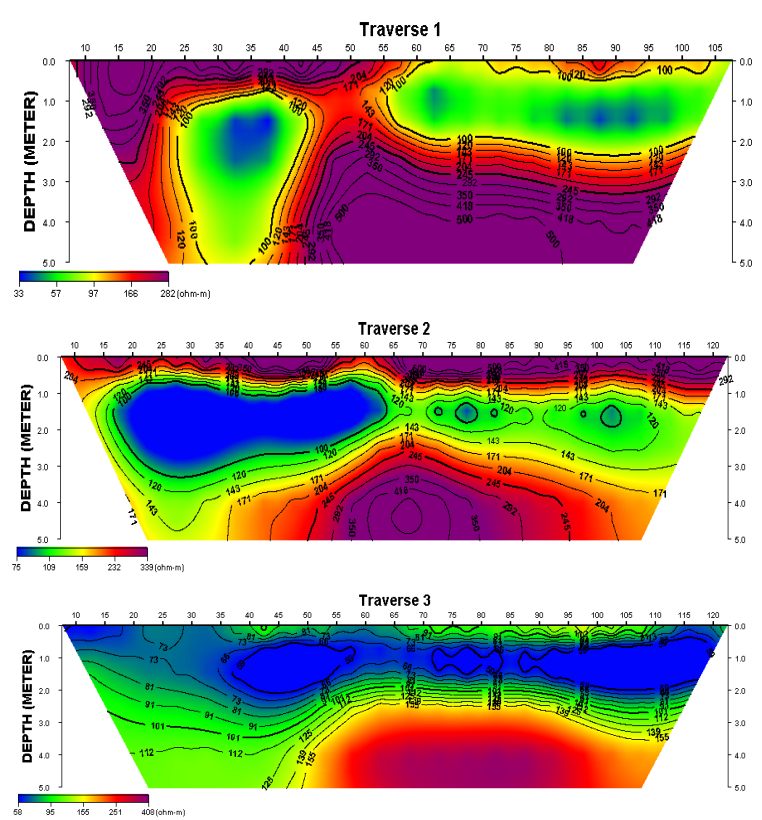

Fig. 3 2D resistivity structure beneath traverses 1-3

\subsection{Physiochemical Assessment}

The results of physicochemical analyses of groundwater collected in the study area are presented in Table 2 . The $\mathrm{pH}$ values of the groundwater analyzed ranged between 6.14 and 6.5 with the mean value of 6.3 for well I, while the $\mathrm{pH}$ values ranged between 6.4 and 6.71 with the mean value of 6.6 for well II. The average $\mathrm{pH}$ of well I fall below the WHO allowable range of 6.5-8.5 for drinking water. This is of great health concern. The acidic nature of the water samples under investigation is probably a reflection of high concentration of $\mathrm{CO}_{2}$ in the atmosphere, leading to acidic rain, a phenomenon that influence the acidity of groundwater in an area. Acidic water has been implicated in a number of disease conditions such as intestinal proliferations and ulcer [17]. The water samples in the study area require $\mathrm{pH}$ treatment to make it potable.

The total dissolved solid (TDS) is a measure of total mineral loads of water. The levels of TDS observed in this study show mean value of 0.032 and $0.038 \mathrm{mg} / \mathrm{L}$ for well I and well II respectively. The level of TDS observed is within the allowable WHO limit of $500 \mathrm{mg} / \mathrm{L}$ for drinking water. The total solids are 0.19 and $0.44 \mathrm{mg} / \mathrm{L}$ for wells I and II respectively which, show that the level of total suspended solid of the water is higher than TDS. This is a reflection of the possible high level of sand or silt, which corroborate the results of Vertical Electric Sounding of the study area. The concentration of anions in this study shows that the water samples are potable. Absence of nitrate in the water and phosphate shows that the area is possibly not under the influence of organic pollution. The sulphate concentration is 0.57 and $0.40 \mathrm{mg} / \mathrm{L}$ respectively for the well I and II respectively, which is lower when compared with the
WHO acceptable limit of $500 \mathrm{mg} / \mathrm{L}$, while the chloride concentration is $0.29 \mathrm{mg} / \mathrm{L}$ for well I and $0.37 \mathrm{mg} / \mathrm{L}$ for well II. A high chloride concentration may harm metallic pipe as well as growing plant with daily intake as $250 \mathrm{mg} / \mathrm{L}$.

The lead $(\mathrm{Pb})$ concentration of the study area observed was 0.10 and $0.59 \mathrm{mg} / \mathrm{L}$ for the well I and II respectively; it was found that the wells have more lead concentration when compared with the WHO acceptable limit of $0.01 \mathrm{mg} / \mathrm{L}$. Lead is toxic metal, it accumulates in kidney and skeleton. Infant, children up to age 6 years and pregnant women are most susceptible to its adverse effects. Lead inhibits the activity of d-amino laevulin dehydrate, thereby affecting the intelligence quotient in infant, renal tumor carcinogenicity in adults are some other side effects [18].

The level of concentration of iron in the water sample under investigation $0.10 \mathrm{mg} / \mathrm{L}$ is below the daily intake WHO acceptable limit of $0.3 \mathrm{mg} / \mathrm{L}$. Amadi et al. [19] pointed out that $\mathrm{pH}$ is an important factor that influences the solubility and resultant concentration of iron. The main sources of iron in groundwater include soil surface urban run- off applications of chemicals and fertilizer, leachates from dumpsites. The geology of the area could also be additional source of the element iron [20] Iron is an essential element in human nutrient it helps in formation of the hemoglobin, however when it exists in very high concentration, it leads to iron toxicity. The values concentration of zinc in samples analysed are 0.28 and $0.03 \mathrm{mg} / \mathrm{L}$ for wells I and II respectively, while the values for copper is 0.04 and $0.06 \mathrm{mg} / \mathrm{L}$ for wells I and II respectively which is below WHO limits for drinking water. The physiochemical assessment of groundwater in this study area put the water analyzed as fresh and soft with acidic $\mathrm{pH}$ values. Majority of the quality parameters investigated were found below the WHO limits except lead as shown in Table 2.

Table 2 Comparison of results of physicochemical parameters with WHO

\begin{tabular}{llll}
\hline Parameter $(\mathrm{mg} / \mathrm{L})$ & Well I & Well II & WHO [21] \\
\hline Total dissolved solid & 0.032 & 0.038 & 500 \\
Total solid & 0.19 & 0.44 & - \\
Sulphate & 0.57 & 0.40 & 400 \\
Chloride & 0.29 & 0.37 & 250 \\
Lead & 0.10 & 0.59 & 0.01 \\
Iron & 0.10 & 0.10 & 0.3 \\
Zinc & 0.28 & 0.03 & \\
Copper & 0.04 & 0.06 & 2.0 \\
Sodium & 7.82 & 5.06 & 200 \\
\hline
\end{tabular}

\section{Conclusion}

Ten vertical electrical sounding (VES) with Schlumberger electrode array was conducted around Iba nursery/primary school, Iba local development area, Lagos State. The study was done with the aim of providing valuable information on its groundwater quality potential within the study area. The interpreted VES data were integrated with the 2-D which revealed four-five geo-electrical layers and this layer correspond to clay, clayey sand, sandy clay and sand. The unconfined aquifer is found to exist within the upper layers with resistivity ranging from 135.4 to $399.4 \Omega \mathrm{m}$. It is composed of sand formation with the thickness ranges from 0.8 to $2.76 \mathrm{~m}$. This is a very thin unconfined bed, close to the surface and will therefore be prone to contamination. Consequently, this aquifer is unreliable and will not yield portable water. The confined aquifer is found in the fourth layer, is composed of sand with resistivity between 100 to $360 \Omega \mathrm{m}$. This is an indication that portable groundwater exists within the depth range of 10 to $20 \mathrm{~m}$, with thickness of this aquifer ranges from 16 to $120 \mathrm{~m}$.

The interpretation of the physiochemical assessment result from the hand dug wells show that the water quality of the study area is wholesome with majority of the quality parameters investigated was found below the WHO limits except lead. However, the water in the study area requires $\mathrm{pH}$ treatment. The ground water resources can best be exploited through boreholes at VES 4, 8 and 9 not by hand-dug wells which are close to the surface and prone to pollution. It is therefore recommended that borehole for sustainable water supply should be drilled not less than $20 \mathrm{~m}$.

\section{References}

[1] A.U. Oteri, F.P. Atolagbe, Saltwater intrusion into coastal aquifers in Nigeria; the second international conference on saltwater intrusion and coastal aquifers monitoring, modeling, and management, Mérida, Yucatán, México, March 30 April 2, 2003.

[2] S.S. Abdul Nassir, M.H. Loke, C.Y. Lee, M.N. Nawawi, Salt-water Intrusion mapping by geoelectrical imaging surveys. Geophys. Prospect 48 (2000) 647 661. 
[3] A.A. Adepelumi, B.D. Ako, T.R. Ajayi, O. Afolabi, E.J. Ometoso, Delineation of saltwater intrusion into the freshwater aquifer of Lekki, Peninsula, Lagos, Nigeria, Environ. Geol. 56 (2008) 927-933.

[4] K.T. Eke, M.U. Igboekwe, Geoelectrical investigation of groundwater in some villages in Ohafia Locality, Abia State, Nigeria, British J. Appl. Sci. Technol. 1(4) (2011) 190-203.

[5] A.R. Zohdy, G.P. Eaton, D.R Mabey, Application of surface Geophysics to ground-

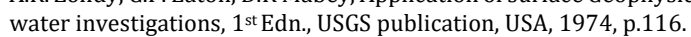

[6] A.A. Bello, V. Makinde, Delineation of the aquifer in the South-Western part of the Nupe Basin, Kwara State, Nigeria, J. Am. Sci. 5 (2007) 36-44.

[7] B.N. Nfor, S.B. Olobaniyi, J.E. Ogala, Extent and distribution of groundwater resources in parts of Anambra state Southeastern, Nigeria. Jour. Appl. Sci. Environ. 11(2) (2007) 215-221.

[8] B.S. Badmus O.B. Olatinsu, Aquifer characteristics and groundwater recharge pattern in typical basement complex: A case study of Federal College of Education, Osiele, Abeokuta, and Southwestern, Nigeria, Afr. Jour. Environ. Sci. Technol. 4(6) (2010) 328-342.

[9] E.O. Longe, L.O. Enekwechi, Investigation on potential groundwater impacts and influence of local hydrogeology on natural attenuation of leachate at a municipal landfill, Int. J. Environ. Sci. Tech. 4 (2007) 133-140.

[10] D. Briggs, Environmental pollution and the global burden of disease, Brit. Med. Bull. 68 (2003) 1-24.

[11] A. Aliewi I. Al-Khatid, Hazard and risk assessment of pollution on the groundwater resources and residents' health of Salfit District, Palestine, Jour. Hydrol. Reg. Stud. 4(B) (2015)472-486.
[12] G.R. Srinivas, G. Nageswarara, Assessment of groundwater quality using water quality index, Arch. Environ. Sci. 7(2013) 1-5.

[13] S.C. Nishanthiny, M. Thushyanthy, T. Barathithasan, S. Saravanan, Irrigation water quality based on hydro chemical analysis, Jaffna, Sri Lanka, Am. Eur. J. Agric. Eviron. Sci. 7(1) (2012) 100-102.

[14] Abdulaziz A. Bassam, M.H. Tahir, Geo-electrical and hydro-chemical methods for groundwater investigations in coastal plains: example from Saudi Arabia, College of Science, King Saud University, Saudi Arabia, 2017.

[15] A. Ochuko, Hydro geophysical and hydrogeological investigations of groundwater resources in Delta Central, Nigeria. J. Sci. Taibah Uni. 9 (2015) $57-$ 68.

[16] APHA / AWWA / WPCF, Standard methods for the examination of water and wastewater, 21 st Ed., APHA / AWWA / WPCF, Washington, 2005.

[17] E.O. Orebiyi, J.A. Awomeso, O.A. Idowu, O. Martins, O. Oguntoke, A.M. Taiwo, Assessment of pollution hazards of shallow well water in Abeokuta and Environs, Southwest, Nigeria, Am. Jour. Environ. Sci. 6 (2010) 50-56.

[18] D.C. Klaassen, O.M. Amodur, J. Doull, Casarett and Doull's Toxicology: The Basic Science of Poisons, $3^{\text {rd }}$ Ed., New York, MacMillan Publishing Company, 1986.

[19] P.A. Amadi, C.O. Ofoogba, T. Morrison, Hydro chemical assessment of groundwater quality in parts of the Niger Delta, Nigeria, Environ. Geol. Water Sci. 14(3) (1989) 195-202.

[20] A.O. Majolagbe, A.A. Kasali, L.O. Ghaniyu, Quality assessment of groundwater in the vicinity of dumpsites in Ifo and Lagos, Southwestern Nigeria, Adv. Appl. Sci. Res. 2 (2011) 289-292.

[21] WHO, Guidelines for drinking-water quality, First addendum to $3^{\text {rd }}$ Ed. 1, WHO (World Health Organization), Geneva, 2006, p.595. 